IRSTI 16.31

\author{
Smagulova G.N. ${ }^{1}$, Aitollakyzy N. ${ }^{2}$ \\ ${ }^{1}$ Doctor of Philology, Professor Al-Farabi Kazakh National University, Almaty, Kazakhstan, \\ ${ }^{2} \mathrm{PhD}$ doctor, Minzu University of China, China, Beijing, \\ e-mail: smagulova.g@mail.ru,nasyra@163.com

\section{FEATURES OF THE SPOKEN LANGUAGE OF THE KAZAKHS LIVING IN CHINA}

The article deals with the peculiarities of the colloquial speech of the Kazakhs living in China in the collected materials of oral speech. The main goal is to prove the regularity of the occurrence of various phonetic, grammatical phenomena that have been preserved in colloquial speech of the Kazakhs of China and are not found in the Kazakh literary language. This process is dependent on the historical situation prevailing among Kazakhs who do not live on their territory, on the linguistic interdependence of ethnic groups living in the neighborhood, on the choice of the profession of the Kazakh language and the way they do business. The language of the Kazakhs living in China was influenced by two different factors. One of them is the external factor, that is, the influence on the development of the language of Chinese, Uigurs and Mongols living side by side with the Kazakhs, another factor is the spoken language of the Kazakhs based on the laws of the internal development of the national language. Bilingualism is characteristic of the language of the Kazakh diaspora, which can be considered as a social factor, since living in a different country implies fluency in the language of a different environment and native language. The article made a comparative analysis of the phonetic, grammatical and lexical features of colloquial speech of the Kazakh diaspora in China and speakers of the Kazakh literary language.

Key words: diaspora, spoken language, bilingualism, word variation, language situation, lexical features.

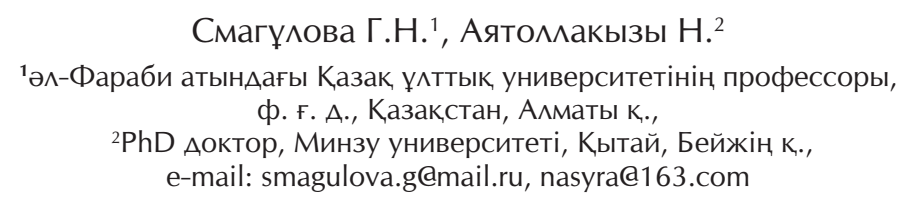

Қытайдағы қазақтардың сөйлеу тікінің ерекшеліктері

Мақалада Қытай қазақтарының сөйлеу тілінен алынған материалдары бойынша ерекшеліктер сөз етіледі. Олардың ауызекі сөйлеу тілінде сақталып, әдеби тілде көп кездесе бермейтін сан алуан фонетикалық, грамматикалық құбылыстар, кездейсоқ пайда болмайтындығы талданады. Мұндай құбылыс өзгешелік тарихи жағдайға, көршілес отырған халықтардың тілдік ықпалына, айналысатын кәсібіне, шаруашылығына байланысты қалыптасқан. Қытайдағы қазақтардың тіліне екі түрлі фактор әсер еткені байқалады. Оның бірі - сыртқы фактор, яғни ғасырлар бойы қоянқолтық аралас өмір сүріп отырған қытай, ұйғыр, азды-көпті моңғол тілдерінің игі әсері болса, екіншісі - жалпы халықтық тілді негіз ете отырып, тілдің ішкі даму заңдылығы бойынша дамуы. Аиаспора тіліне екі тілдік (билингвизм) сипат тән, себебі, өздері мекендеген ел, орта тілін еркін меңгеру мен өз ана тілінде сөйлеу, әлеуметтік фактор ретінде саналады. Мақалада диаспора қазақтары тілінің ерекшеліктері бойынша жиналған фонетикалық, грамматикалық, ^ексикалық, деректер қазақ тілінің әдеби тілмен салыстыра талданады.

Түйін сөздер: диаспора, сөйлеу тілі, билингвизм сөз варианттары, тілдік жағдаят, ^ексикалық, ерекшеліктер. 


\author{
Смагулова Г.Н. ${ }^{1}$, Аятомлакызы Н. ${ }^{2}$ \\ ${ }^{1}$ Аоктор фимологических наук, профессор Казахского национального \\ университета им. аль-Фараби, Казахстан, г. Алматы, \\ ${ }^{2} \mathrm{PhD}$ аоктор, Унверситет Минзу, Китай, г. Пекин, \\ e-mail: smagulova.g@mail.ru, nasyra@163.com \\ Особенности разговорного языка казахов, \\ проживающих в Китае
}

\begin{abstract}
В статье рассматриваются особенности разговорной речи казахов Китая, собранные из материалов устной речи. Основная цель - доказать закономерность возникновения размичных фонетических, грамматических явлений, сохранившихся в разговорной речи казахов Китая и не встречающихся в казахском литературном языке. Этот процесс находится в зависимости от исторической ситуации, сложившейся в среде казахов, проживающих не на своей территории, от языкового взаимовлияния народностей, живущих по сосеАству, от выбора носителями казахского языка профессии и способа ведения ими хозяйства. На язык казахов, проживающих в Китае, повлияли два различных фактора. ОАин из них - внешний фактор, т. е. влияние на развитие языка проживающих бок о бок с казахами китайцев, уйгуров и монголов, другой фактор - разговорный язык казахов, основан на законах внутреннего развития народного языка. Языку диаспоры казахов Китая свойственно двухъязычие (билингвизм), что можно рассматривать как социальный фактор, так как проживание в иной стране предполагает свободное владение языком иной среды и родной речью. В статье слелан сопоставительно-сравнительный анализ фонетических, грамматических и лексических особенностей разговорной речи диаспоры казахов в Китае и носителей казахского митературного языка.
\end{abstract}

Кмючевые слова: Аиаспора, разговорный язык, билингвизм, вариантность слов, языковая ситуация, мексические особенности.

\section{Introduction}

It is typical that there are language features in the spoken language of the Kazakhs who were called as diaspora in theland of immigration. Thus, there is a need to conduct research in the fields of sciencessuch as linguistics, sociology, psychology and cultural studies.

The Kazakh diaspora, which constitutes onethird of the total population of the Kazakh people, is spread over 40 countries around the world. The only thing that unites them is a language.

According to B.Khasanov, who is a researcher of social linguistics, the investigation of language and life of the Kazakhs, who live in foreign countries, is of great importance not only for the Kazakh linguistics, but also for world social linguistics. He claims that «one of the witnesses of being «Kazakh» is a stored language of the Kazakhs who lived in different parts of the world. The evidence of it is a careful usage of a mother tongue in many countries covering four different fields of the Kazakh life such as: life, social life, art, and folklore. Therefore, one source of studies of the Kazakhsis their language.» (Khasanuly B.K., 1992: 8).

It allows us to draw a necessary data about the studiesof the Kazakh language that are investigated in relation with factors such as language of every country, its past, geographic and social environment of inhabitants, spiritual culture, religious beliefs, relations with other nations as well.

A variety of phonetic, grammatical and lexical phenomena, which are kept in the spoken language and which are rare in literary language haven't been appeared by chance. Academician A. Kaydar states that «a language is directly connected with a certain ethnic geneology, a civil history, environment of inhabitants, era of social development, material and spiritual culture, business forms, customs and traditions» (Khaidar A.T., 1998: 66).

Local residents who communicate using literary languageare attracted by the difference in language of Kazakhs living in different regions.

\section{Experiment}

Some features in language difference of people, who came from different parts, draw the attention of the local ethnic groups who communicate by using literary language.

The diaspora living outside Kazakhstanshould pay attention to the following things in order to find out characteristics of the spoken language and peculiarities of diaspora's language based on phonetic, grammatical and lexical features:

Firstly, historical facts that influenced on the formation of the language of diaspora; Secondly: they should show features of borrowed elements 
through comparing it with languages of neighbouring nations in those areas and their influence caused by them; Thirdly: diaspora should find out common and different features of peculiarities of the Kazakh language through comparison of different levels of the Kazakh language.

Historical situation of diaspora, who came from far countries, is completely different. They bring back a strict preservation of the indigenous Kazakh language. Consequently, we can say that not only the Kazakh language and traditions of ancestors, but a world life, experience, information and knowledge as well are being moved. Cultural values acquired by diaspora in foreign countriesare very important for the Kazakh people. For example, the KazakhsofChina learned a lot from the Khanzu, the Kazakhs of Mongolia from the Mongolian, the Kazakhs of Iran from the Iranian. This is a source of wealth, which serves to the Kazakhtreasure. «If each Kazakh learns a language of each country fluently, then it is a knowledge» says the President.

The Kazakhs who lived in Mongolia began to move to Kazakhstan since 1992. There are dialectical features preserved in the language of the Kazakhs came from Mongolia, because they use the spoken language fluently for communication with others. If the language of the Kazakhs in Mongolia is consideredas a territorial dialect according to the spread within a region, it is obvious that there is an issue on the status of the language, exactly on social status of language of diaspora, who are spread in various parts of the territory of Kazakhstan in recent years.

The Kazakhs of Afghanistan and Iran moved to Afghanistan and Iran in difficult times, and lived there for about 80 years and now they are moving to their birthplace - Kazakhstan. The history of the Kazakhs who moved there began with October Revolution in 1917 and it lasted up to 30 years. Those who moved to Afghanistan are tribes of OrtaZhuz (middle tribe) - Argyn, Konyrat and KishiZhuz (a junior tribe) - Aday, Tabyn, Kete, Shomekey. According to historical data, the Kazakhs lived together with Pushtu, Persians, Uzbeks, and Türkmens for many years. As a result, some linguistic and ethnographic features are peculiar for these Kazakhs.

Investigation of thehistory, ethnography, ethnic group and linguistic features of the Kazakhs of Afghanistan and Iran began in 1993, when they started to come back to Kazakhstan. Journalistic articles, papers and some materials of collections about Afghan and Iranian Kazakhs began to appear on the pages of media written by people, who worked there, by Kazakh scientists and public figures who were in business trips.
The Kazakhs who came from Karakalpak region can be investigated by division of them into two groups. The Kazakhs, who moved from Syr with Karakalpaks from the ancient times and who interacted with the Karakalpaks of northen parts, belong to the first group. The second group consists of the Kazakhs of southern areas, who moved from western part of Kazakhstan and settled between the Uzbeks and the Turkmens.

In spite of the fact that the ethnic group of Tajik inhabitants belongs to KishiZhuz (a junior tribe) of the Kazakhs, it is noticeable that there are mainly words peculiar to the southern part in the spoken language according to features of language (Nakisbekov O.N.,1982: 35).

\section{Results and discussion}

Linguistic feature (bilingualism) is typical for the language of diaspora, because speaking both local language and their mother tongue fluently is a social factor. In this article, we are going to draw your attention on linguistic features of the language of the Kazakhs of China.

There are two factors that influencedonthe language of the Kazakhs of China. One of them is an external factor which is a positive affect of languages such as Chinese, Uighur and Mongolian languages that lived cohesively for centuries. The second one is an internal development of language based on national language.

Professor GynShymin is one of scholars who paid attention to the language of the Kazakhs of China. The scientist described in detail features of language of the Kazakhs living in this region in his work called "Grammar of the Kazakh language». (Gyn Shymin., 1998: 59).

The scientist claims that there is no huge difference in the language of the Kazakhs living in China and the Kazakhs of China have kept the integrity of the language. Nevertheless, there are still some linguistic features. The scientist investigates the language of the Kazakhs of China dividing it into two groups: dialects of south-eastern region and dialects of north-western region.

According to the scientist GynShymin the formation of literary language of the Kazakhs of China takes its basis from a north-eastern part due to comparison of both regions and taking into account a broad territory of north-easternpartand a huge number of people as well.

Zhakyp Myrzakhanuly is one of researchers who wrote about the language of the Kazakhs of China. He says that the history of formation of feature of 
the Kazakh language dates back to the ancienttribal stages of development, but the Kazakh language has become a common language of the people and so there are languages of tribes that are undergone phonetic and lexical differences (Myrzakhanuly Zh.,1992: 4).

Nurgabyl SoltanSharipuly is a person who paid attention to the language of the Kazakhs of China. He described some phonetic features of languages of both regions in his article»Phonetic features of the Kazakhs of Jungo Xinjiang and the Kazaks living in Kazakhstan» (Soltansharypuly N.,1993: 20).

Chyn Yanyan says: "The Kazakh language has become a language that crossed borderdue to historical reasons of being settled in two group countries. There are some linguistic differences between languages of the Kazakhs of China and the Kazakhs of Kazakhstan because of the different national language policy, as well as the degree of economical, social development of culture of both parts and difference in the degree of influence caused by other languages in spite of having numerous similarities which is explained by a common roots of the Kazakh people settled in two different areas. Of course, the geographical environment and social culture of both countries have an impact on it «[Chyn Yanyan., 2000:239).

We should also mention the work of Zh. Bolatov called «Local features of the language of the Kazakhs of China». (Almaty: Gylym, 1990.-38 p.)

Summarizing the nature of the studies oflanguage of the Kazakhs of China, first of all, we can say that the language of the Kazakhs of China has still being scientifically investigated in a comprehensive way up to now. Features of language of the Kazakhs of China are mostly studied by Chinese scholars. However, these studies are not totally complete. They are often disordered. The reason of it is explained by the fact that some scientists compare the language of the Kazakhs of China with the language of the Kazakhs of Kazakhstan taking into account only general descriptions.

We can identify the following three factors that have influenced on formation of their language features:

The first is signs of features of local language in motherland; the second is loan words and linguistic phenomena caused by interaction with local Chinese, Uighur, Dungan people; the third isan indirect transformation of other linguistic units into «this type of speech»through the Uighur language.

The use of local features of language and shortening of literary language by the speaker - all of them are features of a spoken language. It is not necessary that all members of sentence are present in a spoken language according to its style. Speaker's intention and idea can also be accompanied by gesture, movement and intonation as well. According to phonetic features, the Kazakh words are pronounced closed and in a soft waybyDiaspora. For example, the sound a is pronounced closed in certain words in the language of Kazakh diaspora. For example:

жаңағыј - жәңегі асылы - әсілі шашу - чәшу

жаңа ғана - жәңе ғана мысалы - місәлі мазақ - мәзәқ

This is commonfor language of the Kazakhs of China. This phenomenon occurs in the languageoflocal Kazakhs. Words, borrowed from the Chinise language are pronounced with a phonetic changes in a spoken language through a syllable-forming units such as merging phonemes into syllable, for example in Chinise language shynmu, yiynmy, and rhythm of sound.For example, Гүпүңжи (Güpüñii) - Gufengji - a wind suction - gypyydzij 鼓风机; Toba Toba - a floor wiper -Tuoba 拖把; Пәйсүр (Päysür) - paichusuo - a police department - pajsur 派出所.

Phonetic differences also vary according to the age and social status of the Kazakh people and as a result variants of words may appear. Becauseadults adapt pronunciation ofloan words on their own language, whereas the youth try to keep the original variant of pronunciation of words.

All nationalities in the world interact with one another based on cultural and economic means of communication. We should keep in mind the following thing when talking about lexical features of words borrowed from the Chinese language: not all loan words fill lexical layers of the language. Some professional and terminology lexis are in use. For example: шай (茶), сәй (菜), жусай (非菜), лобы (夢卜), борми (苞 米), жың (斤), жозы (桌), хуасың (花生), шақай (鞋子), лазы (辣子), му (亩), газыр (瓜子), жоса (朱砂), дазыбау (大字报), etc. Сәй (say), жусай (zhusay), борми (bormi), жозы (zhozy), лазы (lazy) are in a number of dialects in Kazakhstan except word maŭ (shay).

Chinese words don't change in structure. In spoken languge morphological transformations are peculiar for loan words borrowed by the language of the Kazakhs of China, especially by the language of the youth: For example: Шужи (手机) :шужи+ым; сәй +лер (很多菜): юпан +мен јuwpan U盘, (优盘).

One of the actual problems of Kazakh language study is language culture. The chief principles of 
literary language is to keep language norms. This tendency was precise for allthe world languages. The researcher S. Bizakov (Bizakov S.B., 2008:3) said: "Culture of Kazakh language - is the big theme which spreads in all areas - lexicology, lexicography, dialectology, orthography and orphoepy - The language is a communication tool of people; and that is why it is always in change. It is the language development.

One of the most important issues of culture is variants of words.

Variants of words are divided into absoluteand related due to variations of speech and writing norms. Absolute variants: miл - тіл (a language), қ̧ыз - қ̧ыз (a girl), ұл - ұл (a boy), cy - cy (a water) etc. Related variants represent words that are close in meaning, but different in style which is often common for the language of diaspora. For example, in the language of the Kazakhs of China қимыл оздыру - іс-шара өткізу (to organize event); далаң, - коридор (a corridor); бөгенай- белгі (a mark); сабақттан түсу - сабақтан шыzу (to leave from a lesson);жалгасты оқу -жалгастырып оқу (to continue reading) etc. There are elements of the Chinese and Uighur languages in some words in language of students came from China. For example: yақыт mошты (uakyt toshty), қыљжалат болу (kyzhalat bolu), зауфан қыылу (zaufan kylu) etc. In this case, the youthof the Kazakh diaspora should first master culture of writing in order to learn literary norms of the Kazakh language.

\section{Conclusion}

In conclusion we can say that the spread of the dominance of the Khanzu language in the language of the Kazakhs of China, appropriateness and inappropriateness of the usage of loan words, purity of language, huge differences in speech and culture of speech are identified.

The use of grammatical transformations, adaptation of the Khanzu words according to the Kazakh language among urban (as well as rural) citizens in the language of youth of the Kazakhs of China showthe lack of culture of speech.

Therefore, the literate people are obliged to comply with the norms of the literary language at any time. If people violate it and use spoken languageboth in speech and writing, they will harm the culture of language. The owner of language loses the civil responsibility over their own language. If this phenomenon develops, there will be no property of the mother tongue in order to pass it for next generation.

Therefore, we have a suggestion about the future status of diaspora's language. Literary norms of the language of each era arenotas the same as norms of today's language. Additionally, norms of literary language vary depending on the social status of each period. For this reason, there is a need for scientific research of the literary language of the Kazakh diaspora of China that is a fundamental issue. We should take into account the importance of researches on household and cultural lexis that have been preserved from the time of the last nomadic life and usage of archaic words for the history of language and culture of the nation. Masters and $\mathrm{PhD}$ students are conducting research in this sphere under the guidance of scientists at the faculty of language and literature at the University of Minzu that we know. We - Kazakhstani partners will be glad if the scope of topic widens and the results of the research become a common benefit.

\section{Литература}

Хасанұлы Б. Ана тілі - ата мұра. - Алматы: Жазушы, 1992. - 250 б.

Қайдар Ә. Қазақ тілінің өзекті мәселелері. - Алматы: Ана тілі, 1998. - 304 б.

Нақысбеков О. Қазақ тілінің оңтүстік говорлар тобы. - Алматы, 1982. - 166 б.

Гың Шымин. Қазіргі қазақ тілі грамматикасы. - Пекин: Орталық ұлттар университеті, 1998. - 291 б.

Мырзаханұлы Жақып. Қазақ халқы және оның салт-санасы. - Үрімжі: Шыңжаң халық баспасы, 1992. - 598 б.

Солтаншарыпұлы Н. Шыңжаң қазақтары мен Қазақстан қазақтарының тіліндегі кейбір дыбыстық айырмашылықтар // Тіл және аударма. - Үрімші, 1993. - 8-20 бб.

Чын Янян. Қазіргі қазақ тілінің лексикологиясынан зерттеулер. - Пекин: Ұлттық баспа, 2000. - 242 б.

Бизақов С. Сөз нұсқалары және балама атаулар. -Алматы: Самара-Принт, 2008.-507 б.

\section{Reference}

Bizakov S.(2008) Soz nuskalary jane balama ataular [Word versions and alternative names] Almaty:Samara-Print: 2008. 507 p.(in Kazakh) 
GynShymin. (1998) Kazirgi Kazak tilinin grammatikasy [Modern Kazakhgrammar]. Beijing: National Central University: 1998. 291 p.(in Kazakh)

Myrzakhanuly Zhakyp. (1992) Kazakkhalky men onyn salt-sanasy [The Kazakh people and their customs]. Urimzhi: Xinjiang People's Publishing House, 1992. 598 p.(in Kazakh)

Nakisbekov O. (1982) Kazak tilinin ontustik govorlar toby [A group of southern Kazakhs in the Kazakh language]. Almaty: 1982. 166 p.(in Kazakh)

Khaidar A. (1998) Kazak tilinin ozekti maseleleri [Actual problems of the Kazakh language]. Almaty: Ana tili, 1998. 304 p.(in Kazakh)

Khasanuly B. (1992) Ana tili [Native language]. - Atamura. - Almaty: Zhazushy, 1992. 250 p.(in Kazakh)

Soltansharypuly N. (1993) Shynzhan kazaktary men Kazakhstan kazaktarynyn tilindegi keibir dybystyk aiyrmashylyktar [Sound differences in the speech of the Xinjiang and Kazakhstan Kazakhs] Til zhane audarma. Urimzhi, 1993. 8-20pp. in Kazakh)

Chyn Yanyan. (2000) Kazirgi kazak tilinin leksikologiasynan zertteuler.[Research on the lexicology of modern Kazakh language] Beijing: Ulttyk baspa, 2000. 242 in Kazakh) 